\title{
The queen behind the dancing king: live experience of spouses of male strippers
}

\author{
Dennis Glen Ramos* \\ Saint Louis University, Baguio City, Philippines
}

\begin{abstract}
Understanding the type of family structure and dynamics of family whose head of the family is a stripper is essential in uncovering the unknown dimension of a unique family. The study wishes to explore the live experiences of spouses of male strippers. It is made to believed that a society is built on a strong family which is the basic unit and a strong committed family commitment would possibly improve quality of life of the society. The study used Qualitative Phenomological Design. Six participants are included in the study with the following inclusion criteria; live in or married for at least six months while husband is still dancing at bars. Structured interview was utilized in the study. Van Khaam method was used in data management. The findings revealed five major themes namely engaging, loving with two sub themes, loving because and loving inspite, struggling with three sub themes: internal struggle and external struggle and economic burden, accepting with two sub themes; resignation and acceptance because of same work and lastly transforming husband. The experience of spouses of male strippers is an evolving journey. The transformation of the spouses and the events attached to the experience has developed the individual into a strong individual. The study recommends that nurses make a planned counseling program for this risk groups to decrease anxiety and stress of spouses of male strippers and make a quality of life research using the same population to better understand the phenomenon.
\end{abstract}

\section{Introduction}

Individual behavioral and emotional reactions depends on the nature of illness or situations, the patients attitude towards it, reactions to others to it and the variables of illness behaviors evoke few behavioral changes in the functioning of the family. Self-concept is important in relationship with other family members. A patient whose self-concept changes because of illness or situations sometimes cannot meet family expectations leads to tension or conflict [1].

The family is a small social system and primary reference group made of two or more persons living together who might be related by blood, marriage, and adoption [2]. The family is characterized by face to face contact, bonds of affection, love, loyalty, emotional and financial commitment, mutual concerns and identity. The family being a social unit performs three functions namely physical function, the ability to provide food and needs, affectional function, meeting emotional needs and primary adaption and lastly, the social functions, the ability to foster self-esteem [3]. And the family is also an important economic unit studied in family economics.

Since the family is a social unit, family dynamics is important. Family dynamics is a defined as a process by which the family functions make decisions, gives support to individual member and copes with everyday change and challenges [3]. Because of the effect of illness and certain situational crisis, family dynamics often changes.

Understanding the type of family structure and dynamics of family whose head of the family is a stripper is essential in uncovering the unknown dimension of a unique family. A stripper or exotic dancer is a person whose occupation involves performing striptease in a public adult entertainment venue such as a strip club. At times, a stripper may be hired to perform at a bachelor party or other private event. The modern male stripper show usually involves full nudity, although sometimes they may retain underwear, especially g-strings, bikini briefs or thongs throughout the show, or only remove all clothing for a brief time. Performances are usually fully choreographed, involve dance routines and a costume of some sort [4]

Research on linkages between lesbianism, homosexuality and stripping, still classified as deviant behavior in conservative social climates. Some exotic dancers become lesbians and bi -sexual because of their isolation from effective social relationships and their overall dissatisfaction [5]. Exotic dancers are continually exploited in the club, if not outside as well. As a result they may develop hostile and frigid attitudes towards men and women and potentially finding greater sexual fulfillment in lesbian and homosexual relationships [6,7].

Statistically, about one out of 10 strippers is married. And only 13.5 percent have kids. The breakdown at any given moment in time is about 12 percent of strippers are rookies in their first year, 55 percent have been there one to five years, 19 percent have been there five to nine years, six percent have been there 10 to 20 years, and eight percent of grizzled old veterans have been there more than 20 year [8].

Research to date focuses on how one becomes an exotic dancer and the adaptations one must endure within this profession [9-11]; the relationships and interactions between dancers and customers [1213]; and the use of neutralization techniques by the dancers in order to justify their occupation and accept the stigmatizing components attached to the role of an exotic dancer [14-17]. Past researchers assume that exotic dancing is a deviant subculture. No research had

Correspondence to: Dennis Glen Ramos, Saint Louis University, Baguio City, Philippines, Tel: 09454218710; E-mail: denski74@yahoo.com

Key words: male stripper, spouses, lived experiences

Received: April 10, 2018; Accepted: April 18, 2018; Published: April 23, 2018 
been closely associated with the spouses of male strippers. The spouses of this strippers are high risk groups in terms of well-being. Thus, the study explored the live experiences of spouses of male strippers. It is made to believed that a society is built on a strong family which is the basic unit and a strong committed family commitment would possibly improve quality of life of the society.

\section{Researchers background}

Understanding on what likely to happen to spouses of male strippers is crucial in the context of family relations and how nurses deals with these clients. I have encountered spouses of male strippers in the place of work of acquaintances and even from friends where they usually hang out. Qualitative research is not new, and this is the third time to conduct such type of research. I acknowledged that I had read topics on family relationship and male stripping only. Further, the researcher list down the bias a log to bracket feelings and some technicalities about the topics under study. To address limitations, I will seek the help and consulted our professor, classmates and noting the comments and suggestions. A reflective diary is done to constantly remind the researcher on his biases.

\section{Significance of the study}

The study is relevant because it addresses current issues in family relationship and dynamics. It provides additional information about the experiences of spouses of male strippers that can be used as springboard for other researchers. The study may also enlighten future nurses on how to deal with this unique family and understand their situations. In nursing education, additional body of knowledge about the experiences of spouses of male strippers can be shared to the student nurses for them to enhance the behaviors of client in relation to psychiatry and community care. In nursing practice, it would enhance the nurses' understanding of family dynamics thereby adopts a counseling and teaching strategies on how to deal with clients at risk.

\section{Methodology}

Design: The study used Qualitative Phenomological Design

Participants: The participants included were 6 spouses of male strippers in the City of Baguio. The inclusion criteria include married or live-in for six months. The participants are namely: Sampaguita : 20 year old, accountancy undergraduate, lived in partner of dancing Juan X for 6 months with a two month old child, Calachuchi: 32 year old, business woman, married to dancing Juan Y with I child, Dahlia: 28-years-old, call center agent, lived in partner of dancing Juan $\mathrm{Z}$ for 14 months year, Daisy: 22-years-old, housewife, lived in partner of dancing Juan B for 18 months with a 8-months-old child and Ponsetia: 25-years-old, Guest relation Officer (GRO), lived in partner of Dancing Juan C for 12 months.

Data Collection: The study used an unstructured interview where follow-up questions were asked to elaborate the lived experiences of spouses of male strippers. They are interviewed in the preferred place like in their homes, coffee shop and fast food chains where there are less customers. Ethical considerations in research was observed such as process consent, respect for the rights of the informants and community. Each interview took 1 hour in the preferred setting. The interviewer utilized voice recorder to capture the interview while the interviewer asked the question and observe for the nonverbal cues of the participant.

Data Analysis and Management: The researchers will utilize the Van Kham Method of data analysis where the researcher obtained a core of common experiences among the informants. From the field notes gathered, 164 data reductions were made. From this reduction, 12 categories were clustered. The categories are group into 8 subthemes to reach the 5 major themes.

Ethical Considerations: Ethical Consideration Guidelines specified by the research ethics committee will be followed. All respondents will be given information about the study. Identifying information will be removed and each interviewee will be given a unique pseudonym and color code. Informants will be given a written consent to participate in the research, voice recordings will be erased, and transcriptions will be disposed-off upon completion of study; and that participants can withdraw at any stage of the process. Guba and Lincoln (1981) for assessing the soundness of a qualitative study which include Credibility, Dependability, Confirmability and Transferability will be observed.

\section{Results and Discussion}

\section{Engaging}

Engaging is the phase of initiating, experimenting and building of relationship. This is the stage where mutual affection and attachment are determined and further progress to a relationship. In this phase, the individuals explore and get a feel for the relationship and the partner (Figure 1).

\section{Sampaguita stated}

"out of curiousity, pumunta kami ng barkada sa bar at natable namin siya. Kinuha ng kasama ko ang number niya at binigay niya number ko. Simula noon, naging textmate kami hanggang naging kami at nabuntis ako." (out of curiosity, we went to the bar to watch men dancing. My friend got his number and gave my number as well. We became text mate until we became partners and eventually got pregnant.)

\section{Calachuchi further stated}

"pumunta ako sa bar para mag-unwind, nakilala ko siya at tinatable for a long time hanggang naging magsweet heart at nagdesisyong magsama na sa iisang bubong." (I went to the bar to unwind, I met him and offered him some macho drinks in the bar. I frequently go to the bar and give him macho drinks until we became sweethearts and later decided to live in one roof.)

When individuals first meet, they exchange very impersonal information and limit the number of different topics they discuss. As they come to know and trust one another more, they will explore more topics (breadth) and share more intimate information about those topics (depth). An enduring romantic relationship would be marked by

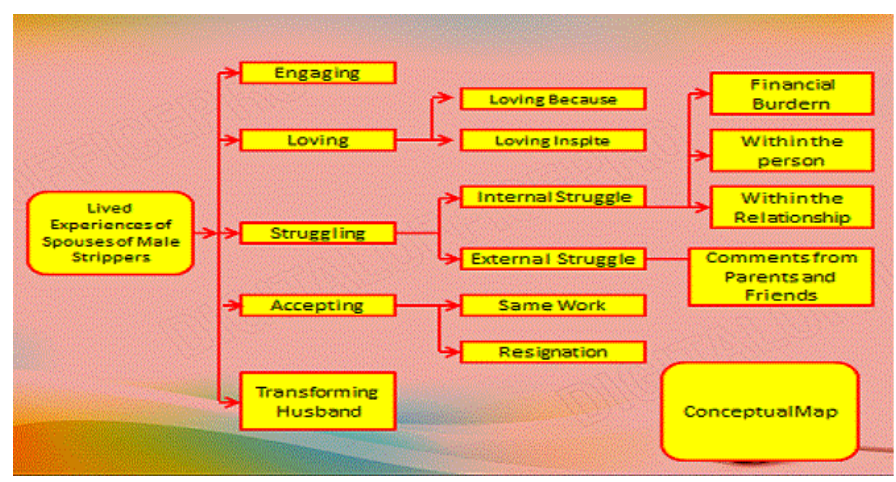

Figure 1. Conceptual map explaining the experiences of spouses of male strippers. 
both breadth and depth. If the exchange is pleasing, they continue the relationship. If it is not, they stop. People are constantly calibrating their ratio of rewards and costs. According to Social Exchange Theories, in addition to assessing how rewarding their relationships are, individuals also consider what other alternative relationships might be available to them and how those potential relationships compare to their current one.

Darwin's theory of evolution explains pairing behaviors by identifying two decisive processes: the preference for a specific partner and the struggle for that partner [18]. This could be explained why some individuals go to bars not just to unwind but scouting for possible partners. This is further expounded by Berger and Calebrese's theory of Incertainty Reductions wherein two unknown individuals meeting for the first time go through various stages to reduce the level of uncertainty between them and come closer to each other. Strangers must communicate well to know each other better and find out their compatibility level. The communication processes people go through in meeting and engaging the interest of another are a vital part of any relationship. If social interaction is rewarding and successful, a relationship may progress into permanency. If the individuals see that the relationship is worthwhile they decide to build and enhance the intimate relationship and further nurture it to a greater level.

Moreover, Social penetration theory explains how romantic images progresses in relationships. The idea in social penetration theory is that intimacy grows as interaction between people penetrates from the outer to inner layers of each person's personality. The meanings we assign to behavior in romantic relationships reflect broad cultural views, which we learn and often internalize. Research on the evolution of romantic relationships from a Western perspective perceives romantic relationships as evolving through growth, navigation, and deterioration [19]. This explains why as you progress from contact through involvement to intimacy, social penetration is likely to increase, including an increase in the breadth and depth of conversation.

Further, when people initially meet and assess each other's attractiveness and availability, people work very hard to present themselves as likeable and interesting. They tend to select their words with caution, knowing that a single mistake may spoil their chances to build a relationship. This is congruent to the research that states "people intentionally engage in strategies to generate affinity" [20]. This is to say, individuals do things to make themselves attractive and likable to others. This explains why in the process of communication is very important in the construct of relationship building specifically in the engaging phase.

\section{Loving}

Loving is the phase which involves a decision to commit himself to others and trying to maintain the love over a period of time. Love is a basic human emotion and understanding how and why it happens must be clearly understood and delineated. Loving has two sub themes namely loving because and loving inspite. Loving because is defined as loving the person with reason and loving inspite is loving the person without barriers and inhibitions.

\section{Calachuchi stated}

"minahal ko siya bilang siya kahit ganun ang trabaho niya. Kung ano man siya ay tanggap ko" (loving Inspite)

\section{However, Dahlia stated:}

"Minahal ko siya kahit ano man siya kasi pinakita niya na handa niya akong ipaglaban." (I loved him whatever he is because he is ready to defend me) (loving because)
Real relationship may be defined as the personal relationship between individual marked by the degree to genuineness and perceives/ experiences the other in ways that befit the other. Thus, the two key elements of the real relationship are genuineness and realism. That is, the guest and the male stripper have fundamentally positive feelings toward each other, even though negative feelings may emerge and be an important part of the relationship. This relationship element may be seen as existing from the first moment of contact between them, and in effective communication likely strengthens throughout the process. Regarding sexual and loving feelings, such reactions may, at least in part, be embedded in the relationship, especially when they occur at certain points in the relationship. Evolutionary approach proposed that in order to conserve the relationship, individuals should be faithful, friendly, generous, understanding and shouldn't reject their partners [21].

Passionate love may occur if you love because of a reason (Loving Because sub-theme). Passionate love is characterized by intense emotions, sexual attraction, anxiety, and affection. When these intense emotions are reciprocated, people feel elated and fulfilled. Thus, clinging into the relationship strengthen the love that is build. This belief is strengthened by Homan's theory of Social Exchange which suggest that "give and take" forms the basis of almost all relationships though their proportions might vary as per the intensity of the relationship. In a relationship, every individual has expectations from his partner. A relationship without expectations is meaningless. Thus, feelings and emotions ought to be reciprocated for a successful and long-lasting relationship. As evident in the study participants like Dahlia solidifies that concept of a passionate kind of love. Sternberg suggests that passionate love arise when expectations encourage falling in love, meets ideas of ideal mate and when individual's experiences heightened physical and emotional arousal of the other person [22]. This might imply that individuals find strength in the love that they built and holds into it for a longer period of time because they are secured at present time or during the relationship.

Unconditional Love occurs when you love someone without any hesitations and accepts the mate holistically (Loving inspite sub-theme). This kind of love crosses different boundaries and defying the odds in the construct of relationship building. In this kind of love, sacrifice is done by a partner. Sacrifice is defined as willing to sacrifice self despite the odds that may develop in the acceptance of the relationship or love. Further, according to Van Lange, Rusbult, Drigotas, Arriaga, Witcher \& Cox, sacrifice is defined as the inclination to give up an immediate personal interest in order to contribute to the spouse's well-being or to the relationship. Sacrifice implies avoiding behaviors that the spouse considers undesirable (passive sacrifice) or promoting those that are desirable to him or her in some way active sacrifice). There are people who tend to make both kinds of sacrifices.

This assertion could be strengthened by the study of Brewer \& Mead, which states that people are willing to sacrifice themselves to attain greater satisfaction and persistence in a relationship and form a more stable bonding or union [23]. This could also explain that sacrifice in close relationships is a determinant of a healthy couple. This may imply that in loving a person sacrifice is made. A selfless act of loving could possible lead to anxieties I relationship which nurse could help contain in the process of mental health. Further, individuals should acknowledge one's identities, values and interest to enhance self-worth and self-esteem.

\section{Struggling}

Struggling is defined as in the study as conflict that may arise from the relationship based on the perception of others and within 
the relationship. Struggles would also literally mean as "a fight to stay alive.” Struggle has three sub themes namely: Internal Struggle, which means struggles within the relationship of the couples, External Struggle, which means struggle from social stigma attached to the relationship and Economic Burden which means financial woes that is encountered in the relationship.

\section{Daisy stated}

"paglumalabas siya sa gabi eh balisa ako. Di ko alam kung pupunta siya sa work o may kameet siya sa labas na ibang babae! (frowns)" (If my husband goes out to work, I feel ambivalent and doubtful if he will be going to work or meet with other girls. Frowns) [Internal Struggle]

\section{Further, Calachuchi stated}

"itinago ko sa mga magulang ko at in-laws ko na may karelasyon akong macho dancer, baka sabihin nilang bakit sa ganun pang lalaki na sumsayaw sa bar ako nagkagusto" (I hide my relationship to my in-laws that I had a relationship with a macho dancer, they might comment why did I got into that kind of relationship.) [external struggle]

\section{Moreover, Sampaguita stated}

"kulang kuya kinikita ng asawa ko, minsan 150 lang binibigay niya sa akin kada gabi. Kung minsan wala. Kaya nagkikiusap ako kay Kuya $\mathrm{X}$ na maglinis sa coffee shop para pandagdag gastos. Teary eyed (The income of my husband is not sufficient. Sometimes he gave my 150 pesos and sometimes none. That is the reason why I go to the coffee shop for extra income to suffice our expenses. Teary eyed) [Financial burden]

The participants expressed different views about struggling. It yields struggles within the relation where doubts and jealousy arise when husband goes to work in the case of Daisy. In some cases, the frequent inquiry by spouses led to physical harm like slapping and sometimes petty fights. Furthermore, Sampaguita expressed economic burden since the income from dancing is not sufficient. According to her, sometimes the husband gives 150 pesos if the bar has little customer. Thus, sometimes she goes out to part time jobs. Moreover, Calachuchi expresses struggles in telling her in laws about the new relationship because of fear that they might despise her for having such relationship. She feared of what will they say about the relationship.

The one who does not know the struggle of life is either an immature soul, or a soul who has risen above the life of this world. The object of a human being is to attain to the perfection of humanity, and therefore it is necessary that man should go through what we call the struggle of life. This coincides with the Evolutionary theory of Darwin which states that to evolve from the self, one must experience the transformation from within through his environment.

Individuals must study the nature of life, he must understand the psychology of the struggle. In order to understand this struggle, one must see that there are three sides: struggle with oneself, struggle with others, and struggle with circumstances. One person may be capable of struggling with himself, but that is not sufficient. Another is able to struggle with others, but even that is not sufficient. A third person may answer the demands of circumstance, but this is not enough also; what is needed is that all three should be studied and learned, and one must be able to manage the struggle in all three directions to cope up with the relationship.

When we consider struggle with others, there are things to remember, control and govern people and activities which happen to be our duty, our responsibility, how to allow ourselves to be used by others in various situations in life; to know to what extent one should allow others to make use of our time, our energy, or our patience, and where to draw the line and lastly how to fit in with the standards and conceptions of different personalities who are at various stages of evolution.

The balance of life depends on thin lines. If one does not show endurance and strength to withstand all the opposing and disturbing influences among which one always has to be in life, one certainly reveals a weakness and lack of development. Sometimes, results might be favorable or unfavorable. With such reaction, it depends on the man's happiness and his progress. If he has control over this reaction, it means that he is progressing; if he has no control over it, it shows that he is going backward.

In one point in time, the person is to meet one's condition with understanding and with complete resignation. Thus, the first thing is to meet the condition as it is and the second is to better the condition. The more one can avoid conflict the better; at the same time, we cannot always avoid a conflict, and we must not turn our back on it if it comes to us.

This is congruent to Knapp's model of Relational Building wherein the couples will be in differentiating stage wherein during this stage, differences between the relationship partners are emphasized and what was thought to be similarities begins to disintegrate. Instead of working together, partners quickly begin to become more individualistic in their attitudes. Differentiating is expected to happen in romantic relationships. A common solution to differentiating is for each partner to give the other "some space" though extreme differentiating can lead to a damaged relationship [24].

\section{Accepting}

Accepting is defined in the study as the act of accepting with approval and favorable reception. There are two sub themes for accepting namely: Resignation, defined as accepting the situation because there is no other possible option and staying in the relationship would be beneficial, and accepting because they have the same work.

\section{Ponsetia stated}

"di ako nahihya na sabihing macho dancer asawa ko, alam din naman ng mga iba kong katrabaho at kaibigan ko na GRO din naman ako. Pareho lang naman kami." (I am not ashamed to tell that my husband is a male stripper. My friends and workmate know this because we are in the same business) [Same work]

\section{Further, Sampaguita stated}

"tinanggap ko na kuya ang sitwasyon ko. Ngayon eh di na ko nahihiya. Tanggap ko ang nangyari sa akin atleast may tatay anak ko." (I accepted my fate. Now I am not ashamed to tell. I accepted my situation at least my child has a so-called father) [Resignation]

Participants viewed accepting in two different views. Resignation is the reason of Sampaguita because she find solace to the relationship. This is somewhat a reason of most Filipinos that strengthen the traditional concept of "andyan na yan, tanggapin na lang". This concept of survival might be beneficial to some couples but most of all could be detrimental to the couples' relationship. Lewis \& Looney states: “The findings regarding main effects raise a question as to whether couples in marital distress can ever "beat the odds" by somehow putting aside the differences between them and forging effective relationships". This 
might mean that spouses could sacrifice herself for the benefit of her child and accepts her fate.

However, Ponsetia viewed acceptance as a mutual consummating relationship. Her acceptance is rooted from the concept that they had the same work and they embrace the same nature of work or profession. A characteristic of Competent but Pained partners was their capacity for objectivity in their appraisals of family relations. Typically, members of a Competent but Pained couple were able to articulate a distinction between their feelings about one another as spouses and their assessments of one another. Although these partners clearly voiced satisfaction with their marriages, they were open to acknowledging. One another's strengths in the domain of nurturing the relationship is essential. Couples in Competent but Pained families made an effort to view family dynamics through the eyes of their environment. Thus, each partner evinced respect for the social attachment to the other. Competent but Pained partners also showed an ability to reflect on their responses to their behaviors. Thus, they perceived that cooperation could enhance their sense of security, whereas conflict could evoke feelings of tension and alarm in them. Seemingly, an incidental finding was Ponsetia finds guest from the guest to her husband. This kind of relationship could be harmful to the couple because they are high risk for sexually transmitted diseases.

Several findings supported the contention that it is important for family researchers to take stock of couples' adaptive resources when attempting to fully account for relational patterns. Clinical family theory, stated that overall marital quality was positively associated with concurrent harmony and negatively associated with concurrent negativity. The study of Haley found evidence that the individual adaptive traits of couples helped to further clarify which families were struggling and which were faring relatively well [25].

\section{Transforming Husband}

Transforming husband is defined in the study as the ability of the spouse to negotiate with the husband to re align the work of the husband to a more self-direct profession away from stripping. Although Transformation is process of realization, the part of bargaining and the acceptance of the mate to proposal is a step-in transformation.

\section{Calachuchi stated}

"nung nagsama na kami. Nagdesisyon na akong wag siyang papasokin sa trabaho at imanage na lang ang business namin na ukayukay." (When we decided to stay together, I decided that he will not work anymore as a stripper and manage our small business)

\section{Dahlia further stated}

"nung sinabi ko sa kanya kung gusto niyang mag aral ng vocational eh, pumayag siya. Kaya yon nag aral siya sa BSBT ng computer programming at ngayon eh nagtratraining na siya sa isang call center." (I asked my husband if he wants to go into vocational school and he agreed to the proposal. He went to BSBT and took up computer programming and now he is training in one of the call center.)

The participants had transformed their husband into a productive individual outside the walls of the bar. The transformation is from being a male stripper to a business manager and a call center agent. Seemingly this are far from the worker they are doing in the clubs or bars. Although the well-off spouses had transformed their husbands, some of the participants had not fully transformed their husband outside the walls of the club but responsibility-wise, they might have as fathers to their children.
Some people who have been in a romantic relationship for years, might say, "until when will I let my husband stop doing this kind of act? What can I do for him to go away from this job?" In order to respond to this way of thinking, individuals offer some alternatives to their mates such that they could be swayed away from this kind of work. Some studies suggest that embracing these transformation processes energizes the relationships and thus, characterizes lasting marriages [26]. This could also be strengthened by the Evolutionary Theory, where it stated there are some factors that may be more significant in explaining the decision to remain in the relationship. These factors are called transformative processes; they energize the relationship and are meaningful motivators that focus on positive transformations rather than on simply increasing the changes in the relationship [26].

Furthermore, this could be explained by Calbrese' Uncertainty Theory that person decides the fate of the relationship. When individuals are comfortable with each other's company, they decide to enter into long term commitments either formally get married or stay together forever to continue their intimate relationship [27]. They give option for each other to improve himself and be productive and useful in the preparation of their family life. Thus, this creates stronger bond between themselves [28]. This further corresponds to Knapps theory of Relational Development wherein in the final stage of the relationship there is what we call bonding. This set the stage that put the relationship on public display and become more exclusive. This involves marriage or any binding contract that signals a change in the relationship, and further strengthen the intimacy of the union [29-31]. This might imply that reaching this stage could not guarantee that relationship will remain forever bonded until this relationship will remain until the spouse's death. Thus, nurses needs to be prepared in handling this kinds of situation and be ready to intervene as necessary [32-34].

\section{Conclusion}

The experience of spouses of male strippers is an evolving journey. The transformation of the spouses and the events attached to the experience has developed the individual into a strong individual. The experience through-out the situation had solidified not only her selfworth but also her ability to sustain the relationship.

\section{Recommendation}

Thus, the research would like to recommend the following:

- Nurses to make a planned counseling program for this risk groups to decrease anxiety and stress of spouses of male strippers,

- Make a quality of life research using the same population to better understand the phenomenon

- Assessment and identification of this risk group must be monitored by health authorities and planning of social program to understand this possible group.

\section{References}

1. Perry A, Potter P (2007) Basic nursing essentials for practice. Mosby Inc.

2. Murray RB, Zenther J (1997) Health assesment and promotion strategies through the life span. Conneticut Appleton and Lange.

3. Gesmundo M (2010) The Basics of Community Health Nursing. C\&E Publishing Inc.

4. Knapp ML, Vangelisti AL (2000) Interpersonal communication and human relationships. Allyn and Bacon, Boston.

5. Boles J, Garbin (1974) The strip club and the customer-stripper patterns of interaction. Sociology and Social Research 58: 136-144. 
6. Peretti PO, Patrick C (1989) Effects of incongruence between the perceived self and the ideal self on emotional stability of stripteasers. Social Behavior and Personality 17: 81-92.

7. James K, Charles H (1970) Stripteasers: The anatomy and career contingencies of a deviant occupation. Social Problems 17.

8. www.11point.com/...Eye|_Openning_Statistics_About_Strippers

9. Calhoun T, Fisher R, Cannon J (1998) The case of amateur stripping: sex codes and egalitarianism in a heterosocial setting. Greenwood Press, Westport.

10. Lewis J (1998) Learning to Strip. The Canadian Journal of Human Sexuality 7: 51-66.

11. Forsyth C, Tina Deshotels (1997) The occupational milieu of the nude dancer. Deviant behavior: an interdisciplinary journal 18: 125-142.

12. Wood EA (2000) Working in the fantasy factory. J Contemp Ethno 29: 5-3.

13. Bowlby J (1969) Attachment and Loss. Basic Books, New York.

14. Peretti PO, Patrick C (1989) Effects of incongruence between the perceived self and the ideal self on emotional stability of stripteasers. Social Behavior and Personality 17: 81-92.

15. Thompson WE, Harred JL (1992) Topless dancers: Managing stigma in a deviant occupation. Deviant Behavior 13: 291-311.

16. Reid S, Jonathon E, Benson DE (1994) Role identity in a devalued occupation: the case of female exotic dancers. Sociological Focus 1: 1-15.

17. Maticka-Tyndale E, Lewis J, Clark JP, Zubick J, Young S (2000) Exotic dancing and health. Women Health 31: 87-108. [Crossref]

18. Darwin C (1871) El origen del hombre. Editores Mexicanos Unidos, México.

19. Mongeau P, Henningson M (2008) Stage theories of relational development. Thousand Oaks, Sage, California pp: 363-375.
20. Bell RA, Daly JA (1984) The affinity-seeking function of communication. Communication Monographs 51: 91-115.

21. Buss DM (2007) The evolution of desire. Strategies for human pairing. Alianza Editorial, Madrid

22. Sternberg R (1986) A triangular theory of love. Psychological Review 93: 119-135.

23. Brewer AL, Mead DE (2008) The oral history rating scale-revised: Preliminary evaluation of a clinician-rated measure of divorce potential. J Divorce Remarr 49: 110 130

24. Rothwell, Dan J (2013) In the company of others. (4th ed.), Oxford University Press pp: 228-229.

25. Kurdek LA, Haley L (1995) Predicting change in marital from husbands' and wives' conflict resolution styles. J Marriage Fam 57: 153-164.

26. Fincham FD, Stanley SM, Beach SR (2007) Transformative processes in marriage: An analysis of emerging trends. J Marriage Fam 69: 275-292. [Crossref]

27. Sternberg R, Gracek S (1984) The Nature of Love. J Personal Soc Psychol 4: 312-329.

28. Sternberg RJ (1999) The theory of successful intelligence. Review of General Psychology 3: 292-316.

29. Gao G (2001) Intimacy, passion and commitment in Chinese and U.S. American romantic relationships. Int J Intercultural Relations 25: 329-342.

30. Homans GC (1961) Social behavior: Its elementary forms. Harcourt, New York.

31. Cuevas F (2007) Department of health, Public health nursing in the Philippines.

32. Calhoun T, Cannon J, Fisher R (1998) Explorations in youth culture: amateur stripping: what we know and what we don't. Blackwell, Malden.

33. Peleg O, Halaby E, Whaby E (2006) The relationship of maternal separation anxiety and differentiation of self to children's separation anxiety and adjustment to kindergarten: a study in Druze families. $J$ Anxiety Disord 20: 973-995. [Crossref]

Copyright: (C2018 Ramos DG. This is an open-access article distributed under the terms of the Creative Commons Attribution License, which permits unrestricted use, distribution, and reproduction in any medium, provided the original author and source are credited. 